\title{
Growth and Yield Attributing Characters of Sprouting Broccoli (Brassica oleracea L. var. italic Planck) as Influenced by Integrated Nutrient Management
}

\author{
Bankey Lal*, A. K. Dubey, Saurabh Dixit, VipulPratap Singh and Satyendra Kumar \\ Department of Vegetable Science, Chandra Shekhar Azad University of Agriculture and \\ Technology, Kalyanpur; Kanpur, India \\ *Corresponding author
}

\section{A B S T R A C T}

\begin{tabular}{l} 
Ke y w o r d s \\
INM, Growth, \\
Azotobacter, \\
Vermicompost, \\
Yield \\
\hline Article Info \\
\hline $\begin{array}{l}\text { Accepted: } \\
\text { 18 December } 2020 \\
\text { Available Online: } \\
\text { 10 January } 2021\end{array}$ \\
\hline
\end{tabular}

Keywords

INM, Growth, Azotobacter, Vermicompost,

\section{Introduction}

Sprouting Broccoli (Brassica oleracea L. var. italica Planck $2 n=2 x=18$ ) is one of the important and potential cole crops belonging to the Brassicaceae family with originated in the Mediterranean region where it has been cultivated since Roman times. It is a rich source of vitamins and minerals. In fact, it contains more vitamin A than cabbage and cauliflower and the highest amount of proteins among the cole crop. It also contains anti-cancerous compounds and antioxidants.
Broccoli is of two types: heading type and sprouting (green and purple) type. Heading broccoli forms curd like cauliflower; while sprouting broccoli contains a group of green immature buds and thick fleshy flower stalk forming a head and more popular in India.

The use of biofertilizers in combination with chemical fertilizers and organic manures offers a great opportunity to increase the production as well as the quality of broccoli (Shree et al., 2014). The incorporation of organic nutrients in the form of 
vermicompost, farmyard manure and biofertilizer is known to influence the physico-chemical and biological properties of the soil resulting in enhanced uptake of nutrients from the soil (Lal and Kanaujia, 2013). Integrated nutrient management having chemical fertilizers applied along with organic sources of nutrients is an effective method for economization of production cost as well as maintenance of soil fertility (Kumar et al., 2011). Organic manure can serve as an alternative practice to mineral fertilizers and microbial biomass (Suresh et al., 2004).Use of organic manures improves soil texture, structure, humus, aeration, water holding capacity and microbial activity(Gupta et al., 2010)and (Dauda et al., 2008). The crops grown with integrated nutrient management techniques are nutritionally and environmentally superior. Therefore, keeping in view the above facts in mind, an attempt has been made in the present investigation to study the Effect of INM practices on growth and yield characters of sprouting broccoli (Brassica oleracea L. var. italica).

\section{Materials and Methods}

The experiment was carried out at the Vegetable Research Station, C. S. A. University of Agriculture and Technology Kalyanpur, Kanpur on sprouting broccoli var. Green Magic during rabi season of 2018-19. The soil of the experimental site was sandy loam having soil $\mathrm{pH} 7.5$, organic carbon 1.20 $\%$, available $\mathrm{N}\left(210.50 \mathrm{~kg} \mathrm{ha}^{-1}\right), \mathrm{P}(45.50 \mathrm{~kg}$ $\mathrm{ha}^{-1}$ ) and $\mathrm{K}\left(195.40 \mathrm{~kg} \mathrm{ha}^{-1}\right)$. The experiment was laid out in a Randomized Block Design (RBD) with three replications. Four weeks old healthy seedlings with uniform vigour were transplanted in 30 October, 2018with plot size that measured $2.40 \times 1.35 \mathrm{~m}$ at the spacing of $60 \times 45 \mathrm{~cm}$. The treatments consisted of $\mathrm{T}_{0^{-}}$ Control, $\mathrm{T}_{1}-100 \%$ RDF (120: 80: 60 N P K $\left.\mathrm{ha}^{-1}\right), \quad \mathrm{T}_{2^{-}} \quad$ FYM $@ 25 \mathrm{t} \quad \mathrm{ha}^{-1}, \quad \mathrm{~T}_{3^{-}}$ Vermicompost @ $5 \mathrm{t} \mathrm{ha}^{-1}, \mathrm{~T}_{4}$ - Azotobacter,
$\mathrm{T}_{5^{-}} 100 \% \mathrm{RDF}+\mathrm{FYM} @ 25 \mathrm{t} \mathrm{ha}^{-1}, \mathrm{~T}_{6^{-}} 100 \%$ $\mathrm{RDF}+$ Vermicompost @ $5 \mathrm{t} \mathrm{ha}^{-1}, \mathrm{~T}_{7^{-}} 100 \%$ RDF + Azotobacter, $\mathrm{T}_{8}$ - Vermicompost @ $5 \mathrm{t}$ $\mathrm{ha}^{-1}+$ Azotobacter, T9- 100\% RDF + FYM @ $25 \mathrm{tha}^{-1}+$ Azotobacter, $\mathrm{T}_{10^{-}} 100 \% \mathrm{RDF}+$ Vermicompost@5 t ha ${ }^{-1}+$ Azotobacter and $\mathrm{T}_{11^{-}} 100 \% \mathrm{RDF}+\mathrm{FYM} @ 12.5 \mathrm{t} \mathrm{ha}^{-1}+$ Vermicompost@2.5 t ha ${ }^{-1}+$ Azotobacter. The full dose of $\mathrm{P}$ and $\mathrm{K}$ and half dose of $\mathrm{N}$ were applied at the time of transplanting and the remaining half dose of $\mathrm{N}$ was given in two equal doses at 30 and 60 days after transplanting. The source of nitrogen, phosphorus and potash were urea, diammonium phosphate and muriate of potash, respectively. Recommended cultural practices were followed to raise a successful crop. Observations on growth and yield attributing characters were recorded in each replication of all the treatments during the investigation. The observations recorded for growth and yield attributing characters viz. plant height $(\mathrm{cm})$, number of leaves plant $^{-1}$, leaf length $(\mathrm{cm})$, leaf width $(\mathrm{cm})$, plant spreading $(\mathrm{cm})$, days of first curd initiation, days to $50 \%$ curd initiation, days to curd maturity, stalk diameter $(\mathrm{cm})$, stalk length $(\mathrm{cm})$, curd diameter $(\mathrm{cm})$, curd length $(\mathrm{cm})$, curd width $(\mathrm{cm})$, weight of curd without leaves $(\mathrm{g})$, curd yield $\left(\mathrm{kg}\right.$ plot $\left.^{-1}\right)$ and curd yield $\left(\mathrm{q} \mathrm{ha}{ }^{-1}\right)$.

\section{Results and Discussion}

Inorganic fertilizers with different organic manures along with biofertilizers alone or in combination were found to have a significant effect on growth characters as compared to control (Table 1). The data was taken on plant height $(\mathrm{cm})$, number of leaves plant ${ }^{-1}$ leaf length $(\mathrm{cm})$, leaf width $(\mathrm{cm})$ and plant spreading of broccoli at 30, 60 and harvesting stage after transplanting influenced by significant differences among the treatments. The application of Vermicompost @ $5 \mathrm{t} \mathrm{ha}^{-1}+$ Azotobacter $\left(\mathrm{T}_{8}\right)$ was recorded 
maximum plant height $(27.79,49.13$ and $50.68 \mathrm{~cm}$, respectively), number of leaves plant $^{-1}$ (9.23, 15.93 and 18.33, respectively), leaf length $(9.44,46.86$ and $48.55 \mathrm{~cm}$, respectively), leaf width $(5.28,21.36$ and $23.85 \mathrm{~cm}$, respectively) and plant spreading (37.12, 60.03 and $68.46 \mathrm{~cm}$, respectively). The minimum values of growth characters were recorded in control. The use of biofertilization may be attributed to the physical, chemical and biological properties of soil which help in better nutrient absorption and utilization by plants resulting in better plant growth. This might be attributed to certain growth promoting substances secreted by the biofertilizers which in turn might have led to better root development, better transportation of water, uptake and deposition of nutrients. Meena et al., (2017) reported that higher plant growth parameter in broccoli was recorded with Vermicompost and Azotobacter along with inorganic fertilizers. Similarly, results due to the effect of organic manures and biofertilizer were recorded by Mohapatra et al., (2013), Shree et al., (2014), Kumar et al., (2013), Mal et al., (2015), Mohanta et al., (2018) and Singh et a.,. (2018). These results conform with the findings of the present experiment.

Integrated nutrient application of inorganic fertilizers, organic manures and biofertilizers alone or in combination significantly increased yield and yield attributing characters of broccoli as compared to control (Table 2). The application of Vermicompost @ $5 \mathrm{t} \mathrm{ha}^{-1}+$ Azotobacter $\left(\mathrm{T}_{8}\right)$ were recorded minimum days of first curd initiation (51.00), days to $50 \%$ curd initiation (54.66) and days to curd maturity (71.66).

Table.1 Effect of integrated nutrient management on growth characters at different days after transplanting (DAT) of sprouting broccoli

\begin{tabular}{|c|c|c|c|c|c|c|c|c|c|}
\hline \multirow[t]{2}{*}{ Treatment } & \multicolumn{3}{|c|}{ Plant height(cm) } & \multicolumn{3}{|c|}{$\begin{array}{c}\text { Number of leaves per } \\
\text { plant }\end{array}$} & \multicolumn{3}{|c|}{ Leaf length $(\mathrm{cm})$} \\
\hline & $\begin{array}{c}30 \\
\text { DAT }\end{array}$ & $\begin{array}{c}60 \\
\text { DAT }\end{array}$ & $\begin{array}{c}\text { At } \\
\text { harvest }\end{array}$ & $\begin{array}{c}30 \\
\text { DAT }\end{array}$ & $\begin{array}{c}60 \\
\text { DAT }\end{array}$ & $\begin{array}{c}\text { At } \\
\text { harvest }\end{array}$ & $\begin{array}{c}30 \\
\text { DAT }\end{array}$ & $\begin{array}{c}60 \\
\text { DAT }\end{array}$ & $\begin{array}{c}\text { At } \\
\text { harvest }\end{array}$ \\
\hline $\mathbf{T}_{\mathbf{0}}$ & 18.86 & 39.01 & 40.62 & 5.95 & 11.46 & 12.45 & 5.23 & 33.46 & 36.58 \\
\hline $\mathbf{T}_{1}$ & 21.71 & 45.63 & 49.11 & 7.90 & 13.26 & 15.40 & 8.42 & 36.58 & 37.59 \\
\hline $\mathbf{T}_{2}$ & 23.85 & 47.84 & 48.65 & 7.93 & 14.20 & 14.80 & 8.06 & 34.88 & 38.19 \\
\hline $\mathbf{T}_{\mathbf{3}}$ & 23.80 & 43.62 & 48.20 & 7.46 & 13.40 & 15.80 & 8.15 & 36.52 & 45.63 \\
\hline $\mathbf{T}_{4}$ & 20.63 & 47.08 & 48.54 & 8.33 & 13.86 & 15.86 & 9.36 & 37.71 & 39.43 \\
\hline $\mathbf{T}_{5}$ & 22.54 & 47.36 & 47.82 & 7.86 & 15.00 & 16.73 & 9.55 & 45.56 & 47.36 \\
\hline $\mathbf{T}_{6}$ & 27.78 & 46.36 & 47.87 & 8.33 & 15.01 & 16.26 & 8.41 & 38.93 & 40.50 \\
\hline $\mathbf{T}_{7}$ & 23.07 & 46.54 & 50.13 & 8.33 & 14.80 & 17.36 & 9.37 & 39.41 & 45.20 \\
\hline $\mathbf{T}_{8}$ & 27.79 & 49.13 & 50.68 & 9.23 & 15.93 & 18.33 & 9.44 & 46.86 & 48.55 \\
\hline $\mathbf{T}_{9}$ & 20.83 & 46.46 & 49.78 & 8.26 & 15.46 & 16.00 & 8.19 & 38.44 & 40.90 \\
\hline $\mathbf{T}_{10}$ & 22.22 & 48.97 & 49.58 & 8.06 & 14.66 & 15.93 & 8.87 & 40.68 & 46.48 \\
\hline $\mathbf{T}_{11}$ & 22.74 & 47.60 & 48.68 & 8.13 & 14.46 & 16.10 & 8.24 & 39.52 & 47.54 \\
\hline $\mathrm{SE}(\mathrm{m}) \pm$ & 0.83 & 1.33 & 1.38 & 0.216 & 0.409 & 0.574 & 0.183 & 0.666 & 1.000 \\
\hline $\begin{array}{c}\text { C.D. at } 5 \\
\%\end{array}$ & 2.44 & 3.91 & 4.05 & 0.635 & 1.20 & 1.68 & 0.538 & 1.955 & 2.933 \\
\hline
\end{tabular}


Table.Cont...

\begin{tabular}{|c|c|c|c|c|c|c|}
\hline \multirow[t]{2}{*}{ Treatment } & \multicolumn{3}{|c|}{ Leaf width (cm) } & \multicolumn{3}{|c|}{ Plant spreading(cm) } \\
\hline & 30DAT & 60DAT & At harvest & 30DAT & 60DAT & At harvest \\
\hline $\mathbf{T}_{\mathbf{0}}$ & 2.20 & 14.15 & 15.37 & 25.73 & 47.90 & 52.90 \\
\hline $\mathbf{T}_{1}$ & 4.22 & 16.01 & 17.84 & 31.66 & 50.42 & 59.24 \\
\hline $\mathbf{T}_{2}$ & 4.26 & 16.84 & 18.37 & 32.57 & 54.46 & 55.52 \\
\hline $\mathbf{T}_{\mathbf{3}}$ & 4.34 & 17.37 & 19.33 & 28.82 & 48.44 & 58.12 \\
\hline $\mathbf{T}_{4}$ & 4.68 & 18.00 & 19.48 & 34.40 & 50.78 & 58.56 \\
\hline $\mathbf{T}_{5}$ & 4.40 & 18.48 & 19.34 & 33.26 & 52.72 & 67.29 \\
\hline $\mathbf{T}_{6}$ & 4.22 & 18.34 & 18.84 & 36.17 & 57.53 & 67.20 \\
\hline $\mathbf{T}_{7}$ & 4.54 & 16.24 & 22.50 & 36.14 & 55.86 & 64.93 \\
\hline $\mathbf{T}_{8}$ & 5.28 & 21.36 & 23.85 & 37.12 & 60.03 & 68.46 \\
\hline $\mathbf{T}_{9}$ & 4.16 & 18.14 & 20.36 & 31.37 & 55.53 & 66.19 \\
\hline $\mathbf{T}_{10}$ & 4.07 & 17.40 & 20.85 & 34.02 & 51.58 & 67.30 \\
\hline $\mathbf{T}_{11}$ & 4.21 & 18.03 & 19.94 & 32.47 & 53.87 & 65.96 \\
\hline $\mathrm{SE}(\mathrm{m}) \pm$ & 0.218 & 0.525 & 0.595 & 0.955 & 1.166 & 1.499 \\
\hline C.D. at $5 \%$ & 0.639 & 1.540 & 1.745 & 2.801 & 3.422 & 4.398 \\
\hline
\end{tabular}

Table.2 Effect of integrated nutrient management on yield and yield attributing characters of sprouting broccoli

\begin{tabular}{|l|c|c|c|c|c|c|}
\hline Treatments & $\begin{array}{c}\text { Days to } \\
\text { first curd } \\
\text { initiation }\end{array}$ & $\begin{array}{c}\text { Days to 50 } \\
\text { \% curd } \\
\text { initiation }\end{array}$ & $\begin{array}{c}\text { Stalk } \\
\text { diameter } \\
\text { (cm) }\end{array}$ & $\begin{array}{c}\text { Stalk } \\
\text { length } \\
\text { (cm) }\end{array}$ & $\begin{array}{c}\text { Curd } \\
\text { diameter } \\
\text { (cm) }\end{array}$ & $\begin{array}{c}\text { Curd } \\
\text { length } \\
\text { (cm) }\end{array}$ \\
\hline $\mathbf{T}_{\mathbf{0}}$ & 57.00 & 68.00 & 1.34 & 13.45 & 8.37 & 3.12 \\
\hline $\mathbf{T}_{\mathbf{1}}$ & 52.00 & 57.66 & 2.70 & 15.28 & 9.50 & 4.27 \\
\hline $\mathbf{T}_{\mathbf{2}}$ & 52.33 & 57.66 & 2.50 & 16.05 & 9.26 & 5.04 \\
\hline $\mathbf{T}_{\mathbf{3}}$ & 52.33 & 57.66 & 2.72 & 17.18 & 9.93 & 5.62 \\
\hline $\mathbf{T}_{\mathbf{4}}$ & 52.33 & 56.00 & 2.74 & 19.05 & 9.60 & 5.68 \\
\hline $\mathbf{T}_{\mathbf{5}}$ & 52.33 & 57.00 & 2.51 & 17.80 & 10.96 & 5.03 \\
\hline $\mathbf{T}_{\mathbf{6}}$ & 52.66 & 56.66 & 2.83 & 18.09 & 11.26 & 5.43 \\
\hline $\mathbf{T}_{\mathbf{7}}$ & 53.00 & 57.00 & 2.85 & 18.95 & 12.11 & 5.59 \\
\hline $\mathbf{T}_{\mathbf{8}}$ & 51.00 & 54.66 & 3.19 & 20.74 & 12.89 & 6.80 \\
\hline $\mathbf{T}_{\mathbf{9}}$ & 52.33 & 57.00 & 2.84 & 20.19 & 10.88 & 6.22 \\
\hline $\mathbf{T}_{\mathbf{1 0}}$ & 51.66 & 56.33 & 2.43 & 19.06 & 11.08 & 6.08 \\
\hline $\mathbf{T}_{\mathbf{1 1}}$ & 51.66 & 56.33 & 2.78 & 19.26 & 10.71 & 5.52 \\
\hline $\mathbf{S E}$ (m) $\mathbf{\pm}$ & 0.415 & 0.743 & 0.119 & 0.333 & 0.395 & 0.187 \\
\hline $\mathbf{C D} @ \mathbf{5 \%}$ & 1.220 & 2.181 & 0.352 & 0.977 & 1.158 & 0.547 \\
\hline
\end{tabular}


Table.Cont...

\begin{tabular}{|l|c|c|c|c|c|}
\hline Treatments & $\begin{array}{c}\text { Curd width } \\
\text { (cm) }\end{array}$ & $\begin{array}{c}\text { Days to curd } \\
\text { maturity }\end{array}$ & $\begin{array}{c}\text { Weight of curd } \\
\text { without leaves } \\
(\mathbf{g})\end{array}$ & $\begin{array}{c}\text { Curd yield } \\
\text { (kg plot }^{-\mathbf{1}} \text { ) }\end{array}$ & $\begin{array}{c}\text { Curd yield } \\
\left(\mathbf{q} \mathbf{~ h a}^{-\mathbf{1}} \text { ) }\right.\end{array}$ \\
\hline $\mathbf{T}_{\mathbf{0}}$ & 8.28 & 77.00 & 291.33 & 3.69 & 113.98 \\
\hline $\mathbf{T}_{\mathbf{1}}$ & 9.97 & 75.33 & 343.80 & 4.12 & 127.15 \\
\hline $\mathbf{T}_{\mathbf{2}}$ & 9.92 & 76.66 & 338.73 & 4.06 & 125.30 \\
\hline $\mathbf{T}_{\mathbf{3}}$ & 8.96 & 76.33 & 330.66 & 3.96 & 122.32 \\
\hline $\mathbf{T}_{\mathbf{4}}$ & 9.28 & 76.66 & 334.80 & 4.10 & 123.86 \\
\hline $\mathbf{T}_{\mathbf{5}}$ & 11.01 & 76.00 & 332.53 & 3.98 & 122.93 \\
\hline $\mathbf{T}_{\mathbf{6}}$ & 10.80 & 74.00 & 368.53 & 4.82 & 148.76 \\
\hline $\mathbf{T}_{\mathbf{7}}$ & 11.08 & 72.00 & 357.06 & 5.36 & 165.53 \\
\hline $\mathbf{T}_{\mathbf{8}}$ & 11.72 & 71.66 & 459.40 & 5.80 & 179.21 \\
\hline $\mathbf{T}_{\mathbf{9}}$ & 10.75 & 75.33 & 453.73 & 5.49 & 169.44 \\
\hline $\mathbf{T}_{\mathbf{1 0}}$ & 10.70 & 74.66 & 439.46 & 5.26 & 162.54 \\
\hline $\mathbf{T}_{\mathbf{1 1}}$ & 10.96 & 75.00 & 431.13 & 5.08 & 140.94 \\
\hline $\mathbf{S E} \mathbf{( m )} \mathbf{\pm}$ & 0.251 & 0.833 & 15.166 & 0.281 & 5.666 \\
\hline $\mathbf{C D}$ @ 5\% & 0.736 & 2.445 & 44.492 & 0.826 & 16.624 \\
\hline
\end{tabular}

These finding has also been observed by Westerveld et al., (2003) in cabbage. It was also observed by Chaubeyet al., (2006) in their study on cabbage that higher fertility levels favoured the maturity time whereas the process of growth and development was slower at lower fertility level. The stalk diameter and stalk length were observed that markedly influenced by different treatments. The maximum stalk diameter $(3.19 \mathrm{~cm})$ and stalk length $(20.74 \mathrm{~cm})$ were obtained with the application of Vermicompost @ $5 \mathrm{t} \mathrm{ha}^{-1}+$ Azotobacter $\left(\mathrm{T}_{8}\right)$. This may be due to increased vegetative growth as induced by integrated nutrient management which might account for increased carbohydrate accumulation as a result of increased photosynthesis. Similarly, the maximum curd diameter $(12.89 \mathrm{~cm})$, curd length $(6.80 \mathrm{~cm})$ and curd width $(11.72 \mathrm{~cm})$ were found with the same treatment. The data regarding the effect of integrated nutrient management on curd weight $(\mathrm{g})$, curd yield $\left(\mathrm{kg}\right.$ plot $\left.^{-1}\right)$ and curd yield $\left(\mathrm{q} \mathrm{ha}^{-1}\right)$ showed significant variation obtained by altering the different fertilizer levels among the treatments. The maximum weight of curd without leaves $(459.40 \mathrm{~g})$, curd yield $\left(5.80 \mathrm{~kg} \mathrm{plot}^{-1}\right)$ and curd yield (179.21 q ha ${ }^{-1}$ ) were recorded in the treatment with the combination of Vermicompost @ $5 \mathrm{t} \mathrm{ha}^{-1}+$ Azotobacter $\left(\mathrm{T}_{8}\right)$ followed by $\left(\mathrm{T}_{9}\right)$ with the application of $100 \%$ RDF + FYM @ 25t ha ${ }^{-1}$ + Azotobacter. However, the beneficial role of organic manures and biofertilizers in improving physical, chemical and biological properties of soil, which in turn, help in better nutrient absorption by plants, also resulted in higher values for yield contributing characters. These results conform with the finding of Atal et al., (2019), Akbar et al., (2009), Khan et al., (2009), Kumar et al., (2010) and Chatterjee et al., (2014) also found that Vermicompost and Azotobacter along with inorganic fertilizers maximum yield characters in cabbage and cauliflower.

Based on results, it could be concluded that the application of Vermicompost @ $5 \mathrm{tha}^{-1}+$ Azotobacter $\left(\mathrm{T}_{8}\right)$ was found to be the best 
treatment combination in terms of growth as well as yield attributes characters of sprouting broccoli.

\section{References}

Akbar, S. L., Kumar, V. and Malik, M. F. (2009).Effect of bio-organic fertilizer on the performance of cabbage under western U. P. condition.Annals of Horticulture, 2(2): 204-206.

Atal, M. K., Dwivedi, D. H., Narolia, S. L., Bharty, N. and Kumari, R. (2019).Influence of bio-fertilizer (Rhizobium radiobacter) in association with organic manures on growth and yield of broccoli (Brassica oleracea L. var. italicaPlenck) cv. PalamSamridhi under Lucknow conditions.Journal of Pharmacognosy and Phytochemistry, 1: 604-608.

Chatterjee, R.,Bandhopadhyay, S. and Rana, J. C. (2014). Organic amendments influencing growth, head yield and nitrogen use efficiency in cabbage (Brassicaoleracea var. capitata L.). AmericanInternational Journal of Research in Formal, Applied \& Natural Sciences, 5(1): 90-95.

Chaubey, T., Srivastava, B. K., Singh, Major, Chaubey, P. K. and Rai, M. (2006). Influence of fertility levels and seasons on maturity and morphological traits of cabbage. Veg. Sci. 33(1): 29-33.

Dauda, S. N., Ajayi, F. A. and Ndor, E. (2008).Growth and yield of watermelon (Citrulluslanatus) as affected by poultry manure application.Journal ofAgricultureScien ces, $4: 121-125$.

Gupta, A., Sharma, N. and Samnotra, R. K. (2010).Effect of bio-fertilizers and nitrogen on growth yield and quality traits in knol-khol (Brassica oleraceavar. gongylodes).The Asian Journal of Horticulture, 5 (2): 294-
297.

Khan, N., Dubey, A. P., Ram, P and Mishra, A. (2009). Integrated nutrient management in broccoli (BrassicaoleraceaeL. var. italica Planck). Plant Archives, 9(1): 423-425.

Kumar, S., Verma, M. K. and Yadav, Y. C. (2011).Studies on effect of biofertilizers with chemical fertilizers on growth and yield of cauliflower (Brassica oleracea var. botrytis) cv. Pusa Snowball K-1.Annals of Horticulture, 4(2): 202-205.

Kumar, V.; Kumar, V.; Tyagi, A.K.; Singh,B. and Kumar,N. (2010). Effect of vermicompost on growth and yield of cauliflower (BrassicaoleraceaL.var. botrytis).Progressive Agriculture,10: 197-199.

Kumar, M., Das, B., Prasad, K. K. and Kumar, P. (2013).Effect of integrated nutrient management on growth and yield of broccoli (Brassica oleraceavar.italica) under Jharkhand conditions. Vegetable Science, 40 (1): 117-120.

Lal, S. and Kanaujia, S. P.(2013). Integrated nutrient management in capsicum under low cost polyhouse condition.Annuals of Horticulture, 6(2): 170-177.

Mal, D., Chatterjee, R. and Nimbalkar, K. H. (2015) Effect of vermicompost an inorganic fertilizers on growth, yield and quality of sprouting broccoli (Brassica oleracea L. var. italica Plenck). International Journal of Bioresource and Stress Management, 5(4): 507-512.

Meena, K., Ram, R. B., Meena, M. L., Meena, J. K. and Meena, D. C. (2017)Effect of organic manures and bio-fertilizers on growth, yield and quality of broccoli (Brassica oleracea var. italicaPlenck.) cv. KTS-1. ChemSci Rev Lett., 6(24): 2153-2158. 
Mohanta, R., Nandi, A. K., Mishra, S. P., Pattnaik, A., Hossain, M. M. and Padhiary, A. K. (2018).Effects of integrated nutrient management on growth, yield, quality and economics of sprouting broccoli (Brassica oleracea $(\mathrm{L}$.$) var. italica) cv.$ Shayali.Journal of Pharmacognosy and Phytochemistry, 7(1): 2229-2232.

Mohapatra, S. K., Munsi, P. S. and Mahapatra, P. N. (2013).Effect of integrated nutrient management on growth, yield and economics of broccoli (Brassica oleraceaL. Var. italicaPlenck.).Vegetable Science, 40(1): 69-72.

Shree, S., Singh, V. K. and Kumar, R. (2014).Effect of integrated nutrient management on yield and quality of cauliflower (Brassica oleraceaL. var. botrytis).An International Quarterly Journal of Life Sciences, 9(3): 10531058.

Singh, G., Sarvanan, S., Kerketta, A. and J.
Rajesh(2018).Effect of organic manures and inorganic fertilizers on plant growth, yield and flower bud quality of broccoli (Brassica oleracea var.Italica) cv- Green Magic. Int. J. Pure App. Biosci., 6 (5): 1338-1342.

Singh, V., Shah, Kh. N. and Rana, D. K. (2017).Combined Effect of Organic Manures and Bio-fertilizers on growth and yield of broccoli under Garhwal Himalayan Region.Hort Flora Research Spectrum, 5(4): 345-347.

Suresh, K. D., Sneh, G., Krishn, K. K. and Mool, C. M. (2004).Microbial biomass carbon and microbial activities of soils receiving chemical fertilizers and organic amendments.Archives Agron. Soil Sci., 501: 641-645.

Westerveld, S. M., Mc Donald, M. R., Mckeown, A. W. and Scott, D. (2003). Optimum nitrogen fertilization of summer cabbage in ontario. Acta Horticulture. 627: 211-215.

\section{How to cite this article:}

Bankey Lal, A. K. Dubey, Saurabh Dixit, VipulPratap Singh and Satyendra Kumar. 2021. Growth and Yield Attributing Charactersof Sprouting Broccoli (Brassica oleracea L. var. italic Planck) as Influenced by Integrated Nutrient Management. Int.J.Curr.Microbiol.App.Sci. 10(01): 2711-2717. doi: https://doi.org/10.20546/ijcmas.2021.1001.315 